\title{
Thunderstorm-associated asthma in an inland town in south-eastern Australia. Who is at risk?
}

\author{
S.T. Girgis*, G.B. Marks*, S.H. Downs*, A. Kolbe ${ }^{\#}$, G.N. Car ${ }^{+}$, R. Paton**
}

\begin{abstract}
Thunderstorm-associated asthma in an inland town in south-eastern Australia. Who is at risk? S.T Girgis, G.B. Marks, S.H. Downs, A. Kolbe, G.N. Car, R. Paton. C ERS Journals Ltd 2000.

ABSTRACT: The aim of the study was to characterize patients at risk of asthma exacerbation during spring thunderstorms and identify potential measures to ameliorate the impact of those events.

A case-control study was conducted among patients aged 7-60 yrs, who attended Wagga Hospital (NSW, Australia) for asthma during the period of 1 June 1997 to 31 October 1997. One hundred and eighty-three patients who attended on 30 and 31 October 1997 were the cases and the remaining 121 patients were the controls. Questionnaire data were obtained from $148(81 \%)$ cases and $91(75 \%)$ controls.

One hundred and thirty-eight $(\mathbf{9 5 \%})$ cases who attended during the thunderstorm gave a history of hayfever prior to the event compared to $66(74 \%)$ controls who attended at other times (odds ratio (OR) 6.01, 95\% confidence interval (CI) 2.55$14.15) ; 111(96 \%)$ cases were allergic to rye grass pollen compared to $47(64 \%)$ controls (OR 23.6, 95\% CI 6.6-84.3). Among subjects with a prior diagnosis of asthma (64\% cases and $82 \%$ controls), controls $(56 \%)$ were more likely to be taking inhaled steroids at time of the thunderstorm than cases $(27 \%$, OR $0.3,95 \%$ CI $0.16-0.57)$.

History of hayfever and allergy to rye grass are strong predictors for asthma exacerbation during thunderstorms in spring. The lower rate of inhaled steroid use in thunderstorm cases suggests that this treatment may be effective in preventing severe attacks during thunderstorms.

Eur Respir J 2000; 16: 3-8.
\end{abstract}

\begin{abstract}
*Institute of Respiratory Medicine, University of Sydney, NSW, Australia. " Southwest Centre for Public Health, Greater Murray Area Health Service, Australia. ${ }^{+}$Charles Sturt University, Wagga Wagga, NSW, Australia. **Wagga Community Health Centre, Wagga Wagga, NSW, Australia.
\end{abstract}

Correspondence: S.T. Girgis, Institute for International Health, P.O. Box 1225, Crows Nest, NSW 156, Australia. Fax: 61299266830

\section{Keywords: Allergen}

asthma

grass pollen

inhaled steroids

thunderstorm

Received: June 231999

Accepted after revision March 82000
Numerous studies have documented the association between environmental and climatic conditions and asthma exacerbations [1-5]. Exposures to high levels of ozone, aerosols, nitrogen oxides and sulphur dioxide have been associated with attendance at hospital with asthma [6-8]. Soybean dust released during cargo handling in the port of Barcelona (Spain) was identified as the cause for a series of severe epidemics of exacerbations of asthma [9].

Asthma epidemics have been reported in association with thunderstorms in Melbourne (Australia) [2]; Tamworth (UK) [10] London (UK) [4, 11, 12] and Birmingham (UK) [13]. Several meteorological features such as temperature, high humidity, rainfall, thunderstorm electric or lightening activity have been proposed as possible triggers for severe exacerbations of asthma following a thunderstorm $[4,11]$, However, not all thunderstorms are associated with asthma exacerbations and not all asthma epidemics are preceded by thunderstorms [14].

In the Melbourne epidemic in 1989, investigators found that $100 \%$ of the storm-affected patients suffered from hayfever; and they were significantly more likely to have a positive and more intense skin-prick test response to rye grass pollen $(\mathrm{p}<0.05)$. Similar findings were reported in the Tamworth (UK; 1990), and London (UK; 1994) epidemics $[4,10]$.
Evidence from previous studies suggested that rye grass pollen plays an important role in the aetiology of spring asthma exacerbation in Melbourne and in northern California (USA) [2, 15]. KNOX [16] has demonstrated that pollen grains degranulate on exposure to moisture: releasing pollen granules of respirable size. These observations led to the hypothesis that moisture-induced degranulation of grass pollens is responsible for the severe exacerbations of asthma which occur during thunderstorms [16, 17].

An epidemic of acute exacerbations of asthma occurred in Wagga Wagga (population 55,000) [18] in inland, southeastern Australia on 30 October 1997 following a thunderstorm. The epidemic continued until the following day, by which time 215 people attended Wagga Base Hospital for asthma, of whom 41 were admitted to hospital. Two people had severe, life-threatening attacks and required intubation and ventilation. People in Wagga Wagga are aware of similar, though less severe, episodes accompanying thunderstorms in 1987, 1993 and 1996.

In order to devise a public health approach to the prevention of severe morbidity in subsequent episodes, the current authors conducted a case-control study to characterize the individual risk factors for exacerbations of asthma during thunderstorms. 


\section{Methods}

\section{Study design}

A case-control study was conducted to identify factors, which distinguished people with asthma, who experienced a severe attack during the thunderstorm, from those who experienced exacerbations at other times.

\section{Study population}

The study population consisted of people aged 7-60 yrs who were within $100 \mathrm{~km}$ of Wagga Wagga at the time of the thunderstorm and who had attended Wagga Base Hospital during the period 1st July 1997 to 31st October 1997 with a recorded diagnosis of asthma (International Classification of Diseases 9 Code 493) [19]. Cases were those who attended the emergency department from 12:00 h 30 October until 24:00 h 31 October 1997 and the remaining patients, who attended at other times, were controls in this analysis. The study population was identified from the medical records of Wagga Base Hospital.

Forty subjects attended on more than one occasion during the study period. Each of these subjects was included only once: as either a case or a control. All those who attended during the thunderstorm were classified as cases, regardless of whether they also attended at other times $(n=12)$. An upper age limit of 60 yrs was chosen to minimize the possibility of misclassification of patients with chronic obstructive pulmonary diseases [20]. Children aged $<7$ yrs (11 cases and 78 controls) were also excluded. The authors sort to avoid the problem with misclassification of virus-associated wheezing illness in very young children [21] and also anticipated difficulties in performing skin-prick tests in this age group.

\section{Survey instrument}

A seven-page self-administered questionnaire was deveoped and pilot tested. The first part of the questionnaire consisted of questions about sociodemographic characteristics, including smoking status. Subsequent questions dealt with the subject's location at and around the time of the thunderstorm including: location in the town; whether they were indoors or outdoors; if indoors, whether windows were open or closed. Information was also sought on the incidence and timing of asthma symptoms around the time of the thunderstorm. The next section asked subjects about asthma symptoms (that is, wheeze and chest tightness) and hayfever symptoms (hayfever, nasal allergies and sinus discomfort) during the previous 12 months. In addition, information was sought with regard to previous thunderstorm-associated symptoms, asthma-related hospital admissions or work absenteeism, and treatment for asthma prior to the index hospital attendance.

\section{Skin-prick tests}

Skin-prick tests were performed to identify the presence of allergic sensitization to eight allergens in all members of the study population who consented to this procedure. The allergens tested were Alternaria alternata (fungi), wheat grain, rye grass pollen, Cladosporium (fungi), cotton, cat dander, mixed grains, and house dust mite (Dermatophagoides pteryonissinus). Droplets of the allergen extracts (Hollister-Stier, Elkhart, IN, USA), histamine $10 \mathrm{mg} \cdot \mathrm{mL}^{-1}$ (as a positive control) and saline/glycerol $50 \%$ volume (v)/ $\mathrm{v}$ (as negative control) were applied to the volar surface of the forearm. The skin was pricked with a lancet through each droplet. Fifteen minutes later the maximum weal diameter and its perpendicular were measured to the nearest millimetre. Mean weal diameter $\geq 3 \mathrm{~mm}$ and more than or equal to the glycerine control was defined as a positive response. Tests in which the histamine weal and all allergen weals had a mean diameter $<3 \mathrm{~mm}$ were defined as negative.

\section{Procedure}

The questionnaire, together with an explanatory letter and a reply-paid envelope, was posted to all eligible cases and controls on 1 December 1997. Six weeks later, nonrespondents received a second questionnaire and a reminder note. All subjects, including those who had not responded to the postal questionnaire, were followed-up by telephone to arrange for skin-prick tests to be performed. At least three attempts by telephone were made to contact cases and controls during working hours, in the evening on a weekday, and on a weekend. Subjects were asked to attend the Community Health Centre in Wagga Wagga for skin-prick tests. Those who had not returned their questionnaires were reminded to complete one. In addition, subjects who attended for skin-prick tests were encouraged to complete a questionnaire if they had not already done so.

The study was approved by Ethics Review Committees of the University of Sydney (Australia) and the Greater Murray Area Health Service (Australia).

\section{Data analysis}

Questionnaire data and skin-prick test results were analysed using SAS for windows statistical package (SAS Institute, Cary, NC, USA). Univariate analysis was carried out on potential risk factors associated with having asthmarelated symptoms during the thunderstorm.

A stepwise logistic regression model was used to identify which of the eight allergens tested by skin-prick tests were independent predictors of risk of hospital attendance during the thunderstorm. A second model was used to test the risk for thunderstorm asthma associated with age; sex; number of years lived in Wagga Wagga; previous doctor's diagnosis of asthma; the use of inhaled steroids or other medications; and markers of severe asthma including history of chest tightness on waking in the morning, prior hospitalization for asthma, missed work and limited activity because of asthma [22, 23].

The entry probability for the stepwise procedure was 0.05 and the removal probability was 0.10 . Variables that remained significant at $\mathrm{p}<0.05$ were retained in the model.

A subsidiary cross-sectional analysis was undertaken, using data on cases and controls combined, to test the effect of being outdoors on the risk of having symptoms at the time of onset of the storm. 
Table 1. - Sociodemographic characteristics of subjects

\begin{tabular}{lccc}
\hline Characteristics & $\begin{array}{c}\text { Thunder- } \\
\text { storm } \\
\text { patients } \\
\text { n (\%) }\end{array}$ & $\begin{array}{c}\text { Patients } \\
\text { attending } \\
\text { at other } \\
\text { times n (\%) }\end{array}$ & $\begin{array}{c}\text { p-value for } \\
\text { difference }\end{array}$ \\
\hline $\begin{array}{l}\text { Male } \\
\begin{array}{l}\text { Age mean } \pm \text { SD } \\
\text { Smoke ever age } \geq 18 \\
\text { yrs }\end{array}\end{array}$ & $28 \pm 13.0$ & $38(42)$ & NS \\
$\begin{array}{l}\text { Current smoking age } \\
\geq 18 \text { yrs }\end{array}$ & $52(43)$ & $34(59)$ & NS \\
$\begin{array}{l}\text { Exposure to household } \\
\text { smoking age }<18 \text { yrs }\end{array}$ & $5(23)$ & $9(29)$ & NS \\
\hline
\end{tabular}

NS: nonsignificant.

\section{Results}

\section{Characteristics of study subjects}

There were 183 cases who attended hospital with asthma on the day of the thunderstorm and 121 controls who attended with asthma before 30th October. One hundred and forty-eight cases (81\%) and 95 (78.5\%) controls completed the questionnaire. However, four controls were excluded because they were not in Wagga Wagga on the day of the thunderstorm, resulting in 91 controls. Nineteen of the nonrespondents indicated that they did not wish to participate and one was too ill. In addition, 41 could not be contacted by telephone and their questionnaires were returned undelivered.

One hundred and ninety (82\%) of the questionnaire respondent-subjects had skin-prick tests (116 cases and 74 controls). Of the 49 who did not have skin-prick tests, 21 refused; 15 were not Wagga Wagga residents; and 13 could not be contacted because they had moved or they did not have a telephone.

Subjects who attended at the time of the thunderstorm (cases) were compared with control subjects who attended at other times with respect to sociodemographic characteristics (table 1). Of those who were aged $\geq 18 \mathrm{yrs}, 16 \%$ of the cases were current smokers compared to one-third of the controls (odds ratio (OR) $0.39,95 \%$ confidence intervals (CI) $0.18-0.83, \mathrm{p}=0.01)$.

\section{Skin-prick tests}

Table 2 shows the prevalence of sensitization to the eight allergens tested. Nearly all $(96 \%)$ of the cases who attended the hospital at the time of the thunderstorm were allergic to rye grass pollen and this was a very strong risk factor. Allergy to Cladosporium mould was also an independent risk factor for attending hospital on the day of the thunderstorm. In contrast, allergy to Alternaria was more common in people who attended hospital with asthma at other times (controls) than cases who attended on the day of the thunderstorm.

\section{Location at the time of the thunderstorm}

Being outdoors at the time of the thunderstorm was not a significant risk factor for having an asthma exacerbation which required hospital attendance at that time. Thirtyeight per cent of those who attended at the time of the thunderstorm (cases) and 29\% of those who attended before 30th October (controls) were outdoors during the thunderstorm and $50 \%$ of cases and $40 \%$ of controls were outdoors in the $2 \mathrm{~h}$ before the storm. Similarly, being indoors with closed windows was not a significantly protective factor.

However, it was observed that many of the controls, who did not attend the hospital on the day of the thunderstorm, nevertheless experienced symptoms on that day. For example, 55 (64\%) controls reported wheeze, and $24(29 \%)$ actually sought medical attention (other than at the hospital emergency department) for asthma on the day of the thunderstorm. Among all symptomatic subjects (that is, cases and controls) on the day of the thunderstorm, being outdoors or indoors with open windows between 20:00 $\mathrm{h}$ and 12:00 $\mathrm{h}$ was associated with an increased risk of onset of asthma symptoms at that time compared to being indoors with windows closed (OR 2.11; 95\% CI $1.12-3.97 ; \mathrm{p}=0.02)$.

Of the 137 cases and 55 controls who reported having wheeze in association with the thunderstorm, $109(80 \%)$ cases and $22(40 \%)$ controls started wheezing $2 \mathrm{~h}$ after and continued to wheeze for about $8 \mathrm{~h}$ after the thunderstorm (fig. 1).

Table 2. - Prevalence of sensitization to specific allergens among patients attending hospital during the thunderstorm $(n=116)$ and those attending at other times $(n=74)$

\begin{tabular}{|c|c|c|c|c|c|c|}
\hline & $\begin{array}{c}\text { Thunderstorm } \\
\text { patients } \\
\text { n (\%) }\end{array}$ & $\begin{array}{c}\text { Patients attending } \\
\text { at other times } \\
\text { n }(\%)\end{array}$ & $\begin{array}{l}\text { Unadjusted odds } \\
\text { ratio }\end{array}$ & $\begin{array}{l}\text { Adjusted odds } \\
\text { ratio* }\end{array}$ & $95 \% \mathrm{CI}^{\#}$ & p-value ${ }^{\#}$ \\
\hline Rye grass & $111(96)$ & $47(64)$ & 12.8 & 23.0 & $6.62-84.33$ & 0.0001 \\
\hline Cladosprium & $71(61)$ & $26(35)$ & 2.9 & 2.8 & $1.21-6.29$ & 0.02 \\
\hline Alternaria & $37(32)$ & $31(42)$ & 0.7 & 0.3 & $0.11-0.58$ & 0.001 \\
\hline \multicolumn{7}{|l|}{ House dust } \\
\hline $\begin{array}{l}\text { mite } \\
\text { Cat }\end{array}$ & $\begin{array}{l}78(67) \\
57(49)\end{array}$ & $\begin{array}{l}46(62) \\
25(34)\end{array}$ & $\begin{array}{l}1.2 \\
1.9\end{array}$ & & & $\begin{array}{l}\text { NS } \\
\text { NS }\end{array}$ \\
\hline Mixed grains & $54(47)$ & $18(25)$ & 2.7 & & & NS \\
\hline Wheat grain & $20(26)$ & 9 (12) & 2.5 & & & NS \\
\hline Cotton & $18(16)$ & $1(1)$ & 13.4 & & & NS \\
\hline
\end{tabular}

95\% CI: 95\% confidence intervals; Ns: nonsignificant. *: adjusted for other allergens shown (selected by stepwise logistic regression); ${ }^{\#}$. for adjusted odds ratio. 


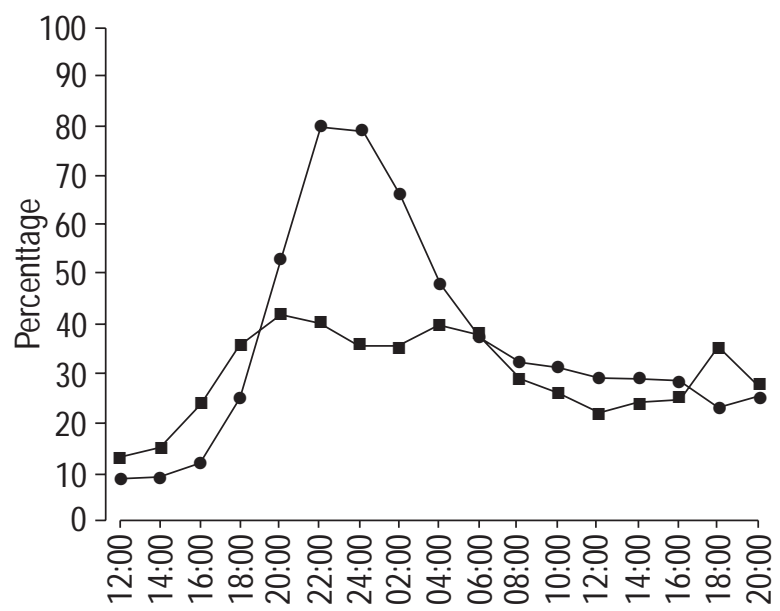

Time of day

Fig. 1. - Proportion of subjects with wheeze on 30th and 31st October 1997. The thunderstorm began at 20:00 h 30th October 1997. @: cases; a: controls.

\section{Previous history of asthma symptoms and hayfever}

Among the thunderstorm asthma cases, the prevalence of recent hayfever was $90 \%$. However, the prevalence of recent wheeze was only $61 \%$. Table 3 shows that, compared to controls who attended the hospital at other times, cases who attended during the thunderstorm were four times more likely to have had hayfever in the 12 months prior to their hospital presentation. In contrast, they were less likely to have had symptoms of asthma prior to their presentation. Fifty-three (36\%) of the thunderstorm cases did not have prior doctor diagnosis of asthma. Less than one-third of cases $(29 \%, n=67)$ reported experiencing

Table 3. - Prevalence of symptoms, healthcare utilization and disability due to asthma and rhinitis among patients attending hospital during the thunderstorm $(n=148)$ and those attending at other times $(n=91)$

Thund- Patients Unad- 95\% CI p-value
erstorm attending justed
patients at other odds
n (\%) times n ratio
$(\%)$

\begin{tabular}{|c|c|c|c|c|c|}
\hline Recent hayfever & $132(90)$ & $62(69)$ & 4.3 & $2.1-8.65$ & 0.001 \\
\hline Recent wheeze & 89 (61) & $67(76)$ & 0.5 & $0.27-0.88$ & 0.02 \\
\hline $\begin{array}{l}\text { Recent chest } \\
\text { tightness }\end{array}$ & $84(58)$ & $65(73)$ & 0.52 & $0.29-0.92$ & 0.02 \\
\hline $\begin{array}{l}\text { Recent morning } \\
\text { chest tightness }\end{array}$ & $54(38)$ & $53(60)$ & 4 & $0.23-0.69$ & .001 \\
\hline asthma & $93(64)$ & $73(82)$ & 0.38 & $0.2-0.73$ & 0.003 \\
\hline $\begin{array}{l}\text { Recent doctor } \\
\text { visit }\end{array}$ & $53(36)$ & $66(73)$ & 0.2 & $0.12-0.36$ & 0.001 \\
\hline $\begin{array}{l}\text { Recent sleep } \\
\text { disturbance }\end{array}$ & $73(51)$ & $66(73)$ & 0.35 & $0.2-0.63$ & 0.001 \\
\hline $\begin{array}{l}\text { Recent hospital } \\
\text { admission }\end{array}$ & $18(12)$ & $26(29)$ & 0.34 & $0.18-0.68$ & 0.002 \\
\hline Limited activity & $54(37)$ & $58(65)$ & 0.33 & $0.19-0.57$ & 0.001 \\
\hline Missed work & $29(20)$ & $44(51)$ & 0.24 & $0.13-0.44$ & 0.001 \\
\hline
\end{tabular}

95\% CI: 95\% confidence interval. wheeze following previous thunderstorms compared to $43(19 \%)$ controls.

Asthma tended to be less severe in the thunderstorm cases than in the controls who had attended hospital at other times (table 3 ). Only $53(36 \%)$ of the cases had sought medical attention and $18(12 \%)$ had been hospitalized for asthma within the prior 12 months. Cases were less likely than controls to report missing work or limited activity during the previous year because of asthma (table 3).

\section{Use of medications}

Subjects' use of medications before the asthma attack which led to hospital attendance during the study period is presented in table 4. Among subjects who had doctordiagnosed asthma, cases were less likely than controls to be taking inhaled steroids once a week or more $(27 \%$ versus $56 \%, \mathrm{p}<0.001$ ) but the two groups did not differ significantly in the frequency with which they used inhaled bronchodilators ( $58 \%$ versus $65 \%$, Ns).

After adjusting for age, sex, years lived in Wagga Wagga, doctor diagnosed asthma, use of other medications and variables related to the severity of asthma, cases were less likely than controls to be taking inhaled steroids (adjusted OR 0.43 ; 95\% CI 0.22-0.87).

Among subjects with doctor-diagnosed asthma, 17 $(19 \%)$ cases had a written asthma management plan (AMP) compared to 29 (41\%) controls (OR 0.33, 95\% CI $0.16-0.67, \mathrm{p}=0.002)$. However, only $9(5 \%)$ cases and 23 $(19 \%)$ controls used their AMP during the asthma episode that required hospital attendance $(\mathrm{p}=0.2)$.

\section{Discussion}

This study supports the findings of previous investigations that allergy to grass pollen and a previous history of hayfever are strong predictors for severe asthma exacerbation following thunderstorms in the grass pollen season. In addition, the authors have presented evidence to suggest that people who were outdoors or indoors with open windows during the thunderstorm had twice the risk of experiencing asthma symptoms at the time of the thunderstorm compared to people indoors with the windows closed. The findings of this study also imply that taking regular inhaled steroid therapy could be effective in the prevention of asthma exacerbation during thunderstorm asthma epidemics.

In this study, the relatively low prevalence of smoking among the thunderstorm patients is surprising. It is possible that the patients attending at other times included some patients with chronic obstructive pulmonary disease (COPD) misdiagnosed as asthma. Patients with COPD would be expected to include a high proportion of smokers. The other possible explanation is that smoking conferred some protection against the effects of thunderstorm-induced airway narrowing. However, there is no plausible biological mechanism for this.

The study has two possible methodological limitations. Firstly, recall bias may have influenced the assessment of risk factors, in particular those concerning subjects' location at the time of the thunderstorm. This was a major 
Table 4. - Use of medications

\begin{tabular}{|c|c|c|c|c|c|}
\hline Medication & $\begin{array}{c}\text { Thund- } \\
\text { erstorm } \\
\text { patients } \\
\mathrm{n}(\%)\end{array}$ & $\begin{array}{c}\text { Patients } \\
\text { attending } \\
\text { at other } \\
\text { times } \\
\text { n }(\%)\end{array}$ & $\begin{array}{l}\text { Unad- } \\
\text { justed } \\
\text { odds } \\
\text { ratio }\end{array}$ & $95 \% \mathrm{CI}$ & p-value \\
\hline All subjects & 148 & 81 & & & \\
\hline $\begin{array}{l}\beta \text { agonist, } \\
\text { short-acting }\end{array}$ & $56(38)$ & $52(58)$ & 0.5 & $0.26-0.77$ & 0.003 \\
\hline Inhaled steroid & $25(17)$ & $42(47)$ & 0.2 & $0.12-0.43$ & 0.001 \\
\hline Cromones & $13(9)$ & $10(11)$ & 0.8 & $0.33-1.86$ & NS \\
\hline LABA* & $2(1)$ & $7(8)$ & 0.2 & $0.03-0.82$ & 0.01 \\
\hline $\begin{array}{l}\text { Subjects with } \\
\text { doctor diag- } \\
\text { nosed asthma }\end{array}$ & 93 & 73 & & & \\
\hline $\begin{array}{l}\beta \text { agonist, } \\
\text { short-acting }\end{array}$ & $53(58)$ & $47(65)$ & 0.7 & $0.39-1.37$ & NS \\
\hline inhaled steroid & $25(27)$ & $40(56)$ & 0.3 & $0.16-0.57$ & 0.001 \\
\hline Cromones & $12(13)$ & $10(14)$ & 0.9 & $0.37-2.29$ & NS \\
\hline LABA* & $2(2)$ & $5(7)$ & 0.2 & $0.05-1.3$ & NS \\
\hline
\end{tabular}

95\% CI: 95\% confidence intervals; NS: nonsignificant. *LABA: long-acting $\beta_{2}$ receptor agonist.

thunderstorm in Wagga Wagga and the authors believe that it is likely that most people would have recalled the event when they subsequently answered the questionnaire. However, it is possible that those subjects who were badly affected had better recall of being outdoors, the time of onset of symptoms and other events around the time of the storm. It is difficult to be certain what effect, if any, this would have on the OR that has been estimated. Secondly, the case control comparisons need to be considered carefully as the study population was chosen to reflect the subset of patients with asthma who experience exacerbations requiring attendance at the emergency department. The study population is not representative of all people with asthma, which may limit the generalizability of the findings. However, it is anticipated that most patients with asthma in Wagga Wagga would use the emergency department service for acute episodes. The data are consistent with previous investigations of thunderstorm asthma epidemics in London, Melbourne, and Tamworth [2, 4, 10].

Allergy to rye grass pollen and history of hayfever has been associated with thunderstorm asthma exacerbation in previous investigations $[2,4,13]$. This is consistent with the findings of the current study in which $95 \%$ of thunderstorm cases were allergic to rye grass and a similar proportion reported prior hayfever symptoms. A severe thunderstorm together with a high grass pollen count prior to the thunderstorm was proposed as the cause of the London epidemic in 1994 [11]. and of the Melbourne epidemic [2, 16, 17]. Daily pollen counts for Wagga Wagga during the period September to November 1997 indicate that the pollen concentration was at its highest in the few days before the epidemic (data not shown). Taken together, these studies provide strong evidence that these exacerbations of asthma are the result of high exposure to grass allergen.

There is a simple evidence from laboratory studies that inhalation of soluble allergen can cause severe and prolonged (or biphasic) bronchoconstriction together with increased airway hyperresponsiveness [24, 25]. The aerodynamic diameter of grass pollen grains varies between $20-120 \mu \mathrm{m}$, which is too large for inhalation into the lower respiratory tract. However there is evidence that pollen allergen is found in association with fine particles as well as grains in the atmosphere, and that these fine particles are small enough to be inhaled [26]. In addition, the atmospheric conditions during thunderstorms may induce grains to rupture and release respirable allergen-containing granules.

The study showed that sensitivity to the fungus Cladosporium was an independent risk factor for hospital attendance with asthma during the thunderstorm whereas sensitization to the fungus Alternaria was not. Earlier work implicates Alternaria exposure as a cause of asthma exacerbation in sensitized individuals although its role during thunderstorms has not been investigated [27-29]. Sensitization to Cladosporium is associated with diagnosis of asthma and rhinitis [30, 31] but the possible importance of the fungus in triggering acute asthma exacerbation has not been previously reported. Aerobiological studies show that levels of Cladosporium spores in ambient air may be amongst the highest of the fungi and its role in causing exacerbations of asthma deserves further investigation $[32,33]$.

To the authors' knowledge, this is the first study to document patients' location during the thunderstorm as a risk factor for experiencing asthma symptoms. Although location at the time of the thunderstorm did not affect the likelihood of having to attend hospital (that is, being a case in this study design), subjects who were outdoors had twice the risk of suffering asthma symptoms at the time of the thunderstorm. If confirmed in subsequent studies this finding would have important implications for the public health advice that should be given to people with asthma, living in affected areas, when thunderstorms are approaching.

The finding that patients with asthma who did not experience a severe attack during the epidemic requiring hospital attendance were more likely to be using inhaled steroids compared to those who attended at the time of the thunderstorm is consistent with the established beneficial effect of this class of drugs preventing exacerbations of asthma [34, 35]. Nevertheless, it should be noted that the estimate of the size of the protective effect of inhaled steroids in thunderstorm epidemics could have been confounded by severity. Thunderstorm cases may have been less likely to be prescribed steroids prior to that event because they had less severe asthma than the controls.

In conclusion, hayfever sufferers and those who are allergic to rye grass pollen are at risk of experiencing exacerbation of asthma symptoms following thunderstorms in the peak grass pollens season. Indeed, these factors are highly sensitive as predictors of risk and seem to be essential prerequisites for severe exacerbations of asthma during spring-time thunderstorms. Some individuals who experience asthma symptoms during these thunderstorms will not have been previously diagnosed with asthma.

The findings of this study suggest that individuals with a history of asthma and hayfever, that is "wheezers and sneezers", who live in areas affected by spring thunderstorm-associated epidemics of asthma, should use inhaled 
steroids during spring. Further investigation is required to establish whether advising such people to stay indoors with the windows closed during thunderstorms in spring is also an effective preventative measure.

Acknowledgements. The authors thank E. Belousova for the data management; W. Xuan for statistical advice; M. Jones for help with skin-prick tests and data collection; D. Quinn and M. Dennis for facilitating the study at Wagga Base Hospital and J. Menz who provided the hospital attendance list.

\section{References}

1. Rosas I, McCartney HA, Payne RW, et al. Analysis of the relationships between environmental factors (aeroallergens, air pollution, and weather) and asthma emergency admissions to a hospital in Mexico City. Allergy 1998; 53 . 394-401.

2. Bellomo R, Gigliotti P, Treloar A, et al. Two consecutive thunderstorm associated epidemics of asthma in the city of Melbourne: the possible role of rye grass pollen. Med $J$ Aust 1992; 156: 834-837.

3. Peat JK. The rising trend in allergic illness: which environmental factors are important? Clin Exp Allergy 1994 24: 797-800.

4. Celenza A, Fothergill J, Kupek E, Shaw RJ. Thunderstorm associated asthma: a detailed analysis of environmental factors. BMJ 1996; 312: 604-607.

5. Jamason P, Laurence S, Kalkstein PG. A synoptic evaluation of asthma hospital admissions in New York City. Am J Respir Crit Care Med 1997; 156: 1781-1788.

6. Rossi OVJ, Kinnula VL, Tienari J, Huhti E. Association of severe asthma attacks with weather, pollen, and air pollutants. Thorax 1993; 48: 244-248.

7. Ayres J. Asthma and the atmosphere. BMJ 1994; 309: 619-620.

8. Anderson HR, Ponce de Leon A, Bland JM, Bower JS, Emberlin J, Strachan DP. Air pollution, pollens, and daily admission for asthma in London. Thorax 1998; 53: 842 848.

9. Antó J, Sunyer J, Rodriguez-Roisin R, Suarez-Cervera M, Vazquez L, Toxicoepidemiological Committee. Community outbreaks of asthma associated with inhalation of soybean dust. $N$ Engl J Med 1989; 320: 1097-1102.

10. Waters J, Corbett S, Gibson P, Hensley M. Epidemic asthma surveillance in the New England Region 19901992. Public Health Bull 1994; 4: 100-101.

11. Newson R, Strachan D, Archibald E, Emberlin J, Hardaker P, Collier C. Effect of thunderstorms and airborne grass pollen on the incidence of acute asthma in England, 1990-94. Thorax 1997; 52: 680-685.

12. Venables KM, Allitt U, Collier CG, et al. Thunderstorm related asthma - the epidemic of 24/25 June 1994. Clin Exp Allergy 1997; 27: 725-736.

13. Packe GE, Ayres JG. Asthma outbreak during a thunderstorm. Lancet 1985; 2: 199-203.

14. Newson R, Strachan D, Archibald E, Emberlin J, Hardaker P, Collier C. Acute asthma epidemics, weather and pollen in England, 1987-1994. Eur Respir J 1998; 11: 694-701.

15. Pollart SM, Reid MJ, Fling JA, Chapman MD, PlattsMills TA. Epidemiology of emergency room asthma in northern California: association with IgE antibody to rye grass pollen. J Allergy Clin Immunol 1988; 82: 224-230.

16. Knox RB. Grass pollen, thunderstorms and asthma. Clin Exp Allergy 1993; 23: 354-359.
17. Suphioglu C, Singh MB, Taylor P, et al. Mechanism of grass pollen-induced asthma. Lancet 1992; 339: 569-572.

18. Australian Bureau of Statistics. 1996 Census Basic Community Profile (electronic). Canberra, Australia, Australian Bureau of Statistics, 1997; cat. no.55519.

19. International Classification of Diseases, ninth revision, clinical modification, ICD-9-CM. 7th Edn. Ann Arbour, MI, USA, 1990

20. Campbell DA, McLennan G, Coates JR, et al. Accuracy of asthma statistics from death certificates in South Australia. Med J Aust 1992; 156: 860-863.

21. Martinez FD, Wright AL, Taussig LM, Holberg CJ, Halonen M, Morgan WJ. Asthma and wheezing in the first six years of life. $N$ Engl J Med 1995; 332: 133-138.

22. Woolcock AJ, Yan K, Salome CM, Sedgwick J, Peat JK. What determines the severity of asthma? Chest $1985 ; 87$ : S209-S213.

23. Wakefield M, Ruffin R, Campbell D, Staugas R, Beilby J, McCaul K. A risk screening questionnaire for adult asthmatics to predict attendance at hospital Emergency Departments. Chest 1997; 112: 1527-1533.

24. Cockcroft DW. Mechanism of perrennial allergic asthma. Lancet 1983; 2: 253-256.

25. Ihre E, Zetterstrom O. Increase in non-specific bronchial responsiveness after repeated inhalation of low doses of allergen. Clin Exp Allergy 1993; 23: 298-305.

26. Schappi GF, Suphioglu C, Taylor PE, Knox RB. Concentrations of the major birch tree allergen Bet v1 in pollen and respirable fine particles in the atmosphere. $J$ Allergy Clin Immunol 1997; 100: 656-661.

27. O'Hollaren MT, Yunginger JW, Offord KP, et al. Exposure to an aeroallergen as a possible precipitating factor in respiratory arrest in young patients with asthma. $N$ Engl $J$ Med 1991; 324: 359-363.

28. Licorish K, Novey HS, Kozak P, Fairshter RD, Wilson AF. Role of Alternaria and Penicillium spores in the pathogenesis of asthma. J Allergy Clin Immunol 1985; 76 : 819-825.

29. Schuktze-Werninghaus G, Levy J, Bergmann EM, Kappos AD, Meier-Sydow J. Clinical significance of airbourne Alternaria tenuis-spores: seasonal symptoms, positive skin and bronchial challenge tests with Alternaria in subjects with asthma and rhinitis. Adv Aerobiology 1987; 51: 153-156.

30. D'Amato G, Chatzigeorgiou G, Corsico R, et al. Evaluation and prevalence of skin prick test positivity to Alternaria and Cladosporium in patients with suspected respiratory allergy. Allergy 1997; 52: 711-716.

31. Tariq SM, Matthews SM, Stevens M, Hakim EA. Sensitization to Alternaria and Cladosporium by the age of 4 years. Clin Exp Allergy 1996; 26: 794-798.

32. Mitakakis TZ, Ong EK, Stevens A, Guest D, Knox BR. Incidence of Cladosporium, Alternaria and total fungal spores in the atmosphere of Melbourne (Australia) over three years. Aerobiologic 1997; 13: 83-90.

33. Herrero B, Zaldivar P. Effects of meterological factors on the levels of Alternaria and Cladosporium spores in the atmosphere of Palencia, 1990-92. Grana 1997; 36: 180184.

34. Blais L, Ernst P, Boivin JF, Suissa S. Inhaled corticosteroids and the prevention of readmission to hospital for asthma. Am J Respir Crit Care Med 1998; 158: 126132.

35. Van-Ganse E, Hubloue I, Vincken W, Leufkens HG, Gregoire J, Ernst P. Actual use of inhaled corticosteroids and risk of hospitalisation: a case-control study. Eur $J$ Clin Pharmacol 1997; 51: 449-454. 